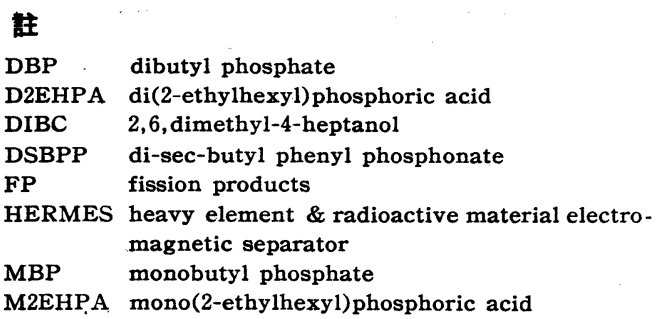

$\begin{array}{ll}\text { MIBK } & \text { methyl isobutyl ketone } \\ \text { NBHA } & \text { n-benzyl-1-(3-ethylpentyl)-4-ethyloctylamine } \\ \text { RE } & \text { rare earths } \\ \mathrm{R}_{3} \mathrm{PO}_{4} & \text { trialkyl phosphate } \\ \text { TBAN } & \text { tetrabutyl ammonium nitrate } \\ \text { TBP } & \text { tributyl phosphate } \\ \text { TBPO } & \text { tributyl phosphine oxide } \\ \text { TnOA } & \text { tri-n-octyl amine } \\ \text { TLA } & \text { trilauryl amine } \\ \text { TOPO } & \text { trioctyl phosphine oxide } \\ \text { TTA } & \text { thenoyl trifluoroacetone }\end{array}$

\section{6 分析試薬}

\section{$6 \cdot 1$ 無}

高純度無機試薬の研究の状況について概説するにあた り, 性状ならびに精製法と分析化学への応用の 2 項にわ けて述べることにする。

\subsection{1 性状ならびに 精製法 分析用基準物質とし} $\tau$, 結晶硫酸鉄アンモニウム $\left(\mathrm{NH}_{4}\right)_{2} \mathrm{SO}_{4} \cdot \mathrm{Fe}\left(\mathrm{SO}_{4}\right) \cdot$ $6 \mathrm{H}_{2} \mathrm{O}$ の純度ならびにその保存性が検討され, 基準物質 として適当であるとの結論がえられた ${ }^{1)}$ ， その他基準物 質の 熱安定性について $\mathrm{NaNO}_{2}, \mathrm{SrS}_{2} \mathrm{O}_{3}, \mathrm{Na}_{2} \mathrm{H}_{3} \mathrm{IO}_{6}$, $\mathrm{AlCl}_{3} \cdot 6 \mathrm{H}_{2} \mathrm{O}, \quad \mathrm{K}_{2} \mathrm{~S}_{2} \mathrm{O}_{8}, \quad \mathrm{Na}_{2} \mathrm{~S}_{2} \mathrm{O}_{7}, \quad \mathrm{FeSO}_{4} \cdot 7 \mathrm{H}_{2} \mathrm{O}$, $\mathrm{NH}_{4}\left[\mathrm{Al}\left(\mathrm{SO}_{4}\right)_{2}\right] \cdot 12 \mathrm{H}_{2} \mathrm{O}, \quad \mathrm{NH}_{4}\left[\mathrm{Fe}\left(\mathrm{SO}_{4}\right)_{2}\right] \cdot 12 \mathrm{H}_{2} \mathrm{O}$, $20 \mathrm{MoO}_{3} \cdot 2 \mathrm{H}_{3} \mathrm{PO}_{4} \cdot 48 \mathrm{H}_{2} \mathrm{O}$ および $\mathrm{Ba}\left(\mathrm{C}_{2} \mathrm{H}_{3} \mathrm{O}_{2}\right)_{2} \mathrm{H}_{2} \mathrm{O}$, $\mathrm{Pb}\left(\mathrm{NO}_{3}\right)_{2}, \mathrm{KNO}_{3}, \mathrm{NH}_{4} \mathrm{NO}_{3}, \mathrm{NH}_{4} \mathrm{C}_{2} \mathrm{H}_{3} \mathrm{O}_{2}, \mathrm{UO}_{2}\left(\mathrm{NO}_{3}\right)_{2}$, $\mathrm{Pb}\left(\mathrm{C}_{2} \mathrm{H}_{3} \mathrm{O}_{2}\right)_{2} \cdot 3 \mathrm{H}_{2} \mathrm{O}, \mathrm{MgCl}_{2}, \mathrm{Co}\left(\mathrm{NO}_{3}\right)_{2}, \mathrm{Na}_{2} \mathrm{~S}$ などの 熱分解曲線をしらべ，その性質が明らかにされた2). ま た米国 NBS で保証された各種の標準試料の発展の模 様, 現状, さらに将来どのように開発されるかの諸問題 について評論されだ)。 同じく NBS では Electrochemical Society と協力し, 標準螢光体 14 種類を標 準試料として, 新製品を出しこれは工業または研究用と して，品質管理および新製品の発展に利用されだ).

高純度の $\mathrm{KBr}$ の精製に関して, 不純物の $\mathrm{Fe}, \mathrm{Pb}$ diethyl dithiocarbamate の Na-塩を用いて精製する 方法について詳述さ秃 ${ }^{5}$ ， そのほか赤外スペクトル測定 用 $\mathrm{KBr}$ の精製法6)てが報告された.

*1 大阪工莱技術試臨所（大阪市大淀区大仁西 2 丁目）

*2 宗都大学薬学部 (京都市左京区吉田近衛町)

*3 九州大学工学部合成化学教室 (福岡市箱崎町)

*4 同仁薬化学研究所 (熊本市出水町今 718)
機

\section{試} 薬

無担保 R. I. の精製については，溶媒抽出による ${ }^{32} \mathrm{P}$ の分離 ${ }^{8}$ および電解法によって ${ }^{140} \mathrm{Ba}-{ }^{140} \mathrm{La}$ 系から放射 化学的純度の高い ${ }^{140} \mathrm{La}$ を迅速に調製する方法の確立 について研究された ${ }^{9)}$. そのほか無担体の ${ }^{35} \mathrm{SO}_{4}{ }^{2-}$. と ${ }^{32} \mathrm{PO}_{4}{ }^{3-}$ との系を陽イオン交換樹脂柱に流し ${ }^{34} \mathrm{SO}_{4}{ }^{3-}$ のみを容易に得た ${ }^{10}$ ). べつに発光分光用純物質について は，塩基性 $\mathrm{MgCO}_{3}, \mathrm{MgO}, \mathrm{NaCl}, \mathrm{Na}_{2} \mathrm{CO}_{3}, \mathrm{CaO}$ な

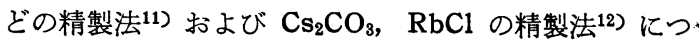
いての報告もある.

またイオン交換樹脂を用いて $\mathrm{Na}_{2} \mathrm{CO}_{3}$ および $\mathrm{NaHCO}_{3}$ ： の製造について Michaels 法 (C. A., 47, 3541) と Walton 法 (C. A., 37，5299）によって研究された ${ }^{13) .}$ $\mathrm{KC1}$ の精製についてイオン移動度を 利用し， あらかじ め精製した $\mathrm{KCl}$ を $\mathrm{NH}_{4} \mathrm{Cl}$ を含む寒天層を通じて純化。 する方法 ${ }^{14)}$ ，また高純度アルカリ塩化物の製造として重 炭酸塩と塩酸からの精製法15) などについての報告があ. る. $\mathrm{LiF}$ の精製法としてはあらかじめ精製した $\mathrm{LiCl}$ ま たは $\mathrm{LiNO}_{3}$ と $\mathrm{NH}_{4} \mathrm{~F}$ とを用いての研究がなされた ${ }^{16)}$. $\mathrm{CaF}_{2}, \mathrm{BaF}_{2}$ の高純度結晶物の製造に，あらかじめ精製: した $\mathrm{BaCl}_{2}, \mathrm{CaCl}_{2}, \mathrm{NaCl}, \mathrm{KCl}$ と純 $\mathrm{KF}, \mathrm{NaF}$ から の方法についての記載がある17).

高純度 $\mathrm{As}_{2} \mathrm{O}_{3}$ の精製については, $\mathrm{As}_{2} \mathrm{O}_{3}$ を $\mathrm{NaOH}$ 溶液にとかして沪過し硫酸々性として $\mathrm{As}_{2} \mathrm{O}_{3}$ の析出結 晶を分離して，これを塩酸で $\mathrm{AsCl}_{3}$ とし水で加水分解 する方法がある18). また高純度 $\mathrm{V}_{2} \mathrm{O}_{5}$ について, ウラン 鉱処理の副産物である Red Cake を塩素化して得た $\mathrm{VOCl}_{3}$ を $\mathrm{NH}_{4} \mathrm{OH}$ で加水分解させ，生成した $\mathrm{NH}_{4} \mathrm{VO}_{\varepsilon}$ : 
を焼成したものの純品は, 不純物 Si は別として Fe, $\mathrm{Cr}, \mathrm{Mo}, \mathrm{Nb}, \mathrm{Ti}$ などは分光分析の検出限界外で, 純 度 $99.99 \%$ であると述べられた ${ }^{19) .}$

基礎試薬として硝酸の精製法ならびにその安定性につ いて 50〜90\% の $\mathrm{HNO}_{3}$ 中の還元性不純物を除去する ため $\mathrm{O}_{3}$ を通ずる研究がある20).

そのほか炭酸塩を含まない高純度 $\mathrm{NaOH}$ 溶液の調製 法として, $\mathrm{N}_{2}$ 気流中で $\mathrm{Na}$ を水に溶解する方法21), ま た $\mathrm{Mn}$ (II ) 標準溶液を調整するため次式により $\mathrm{KMnO}_{4}$ を $\mathrm{H}_{2} \mathrm{O}_{2}$ で還元する方法, すなわち $2 \mathrm{MnO}_{4}^{-}+4 \mathrm{H}_{2} \mathrm{O}_{2}$ $+8 \mathrm{H}^{+} \rightarrow 2 \mathrm{Mn}^{+3}+8 \mathrm{H}_{2} \mathrm{O}+4 \mathrm{O}_{2}$ の原理により得られた $\mathrm{Mn}$ (II) の溶液は $1.5 \mathrm{~N}-\mathrm{HCl}$ で安定であるとのべら れた22). $\mathrm{K}^{+}$と共存する $\mathrm{Na}^{+}, \mathrm{Li}^{+}$の沈殿绪として, (1) $\mathrm{KH}_{2} \mathrm{PO}_{4}, \mathrm{KOH}$, EtOH (2) $\mathrm{KAsO}_{3}, \mathrm{NH}_{4} \mathrm{OH}$, EtOH (3) $\mathrm{K}_{3} \mathrm{PO}_{4}, \mathrm{NH}_{4} \mathrm{OH}, \mathrm{EtOH}$ (4) $\left(\mathrm{NH}_{4}\right)_{3} \mathrm{PO}_{4}$, $\mathrm{NH}_{4} \mathrm{OH}, \mathrm{EtOH}$ などについての実験が行なわれ，とく に $5 \% \mathrm{KH}_{2} \mathrm{PO}_{4}-50 \mathrm{ml}, 5 \% \mathrm{KOH}-50 \mathrm{ml}, 96 \% \mathrm{EtOH}$ $300 \mathrm{ml}$ の組成のものが有効であった ${ }^{23)}$. なお高純度金 属の精製については内外とも多く研究されているがここ では省略する.

6.1.2 分析化学への応用 まず滴定の方面では, 溶 液の 標定方法として $\mathrm{HgCl}_{2}$ の場合, $\mathrm{H}_{2} \mathrm{~S}$ を通じたの ち, Methyl purple を指示薬として $\mathrm{NaOH}$ の標準溶 液で標定する研究がおこなわれた24)。また，スルファミ ン酸が非水溶媒中の Li-methoxide の標定に有効であ るといわれている25). Ammonium tetrathio-cyanatomercurate $\left.{ }^{(203} \mathrm{Hg}\right)$ 溶液が $\mathrm{Cu}, \mathrm{Zn}$ の滴定に用いら れ，このとき指示薬として ${ }^{65} \mathrm{Zn},{ }^{60} \mathrm{Co}$ が使用された ${ }^{26)}$. また標識された黄血塩 $\mathrm{K}_{4}\left[{ }^{59} \mathrm{Fe}(\mathrm{CN})_{6}\right]$ の溶液で $\mathrm{Zn}$, $\mathrm{Pb}(\mathbb{I}), \mathrm{Ag}, \mathrm{Cu}(\mathrm{I})$ などを定量する研究が行なわれ た ${ }^{27)}$. 一方過酸化水素と Na-hypobromite の混合溶液 による $\mathrm{S}^{2-}, \mathrm{SO}_{3}{ }^{2-}, \mathrm{S}_{2} \mathrm{O}_{3}{ }^{2-}, \mathrm{AsO}_{3}{ }^{3-}$ などの定量 ${ }^{28)}$, $\mathrm{SbCl}_{3}$ で濃酰酸中の $\mathrm{CsCl}$ を伝導度法で定量29)する実 験もある. 黄血塩溶液を標準とする金属の滴定について の研究が引き続き今期においてもおこなわれ，Th の定 量法が報告された ${ }^{30}$. ベつにフェロシアンイオンによる $\mathrm{Cu}(\mathbb{I})$ の連続電量滴定法 $\left.{ }^{31}\right)$ の研究があり, また黄血 塭一赤血塩混合規定液を 調製し, 種々の金属について 分 極滴定法の忘用が試みられた ${ }^{32)}$. 新しい試みとして塩化 具素規定液が マレイン酸, フマール酸の定量に用いら れ33), トリリン酸ナトリウムが錯形成剂として利用され Mn の電流滴定がおこなわれた ${ }^{34)}$.

光度法の方面では, 真化水素酸を用い $\mathrm{Pb}$ を $\left[\mathrm{PbBr}_{4}\right]^{2-}$ 錯イオンに変え $\mathrm{Pb}$ の紫外分光光度定量, 同様の原理で

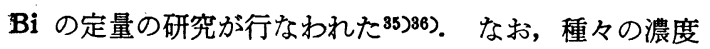

のヒドロニウムイオンおよび $\mathrm{Cl}^{-}$を含む $\mathrm{Sn}(\mathrm{N})$ 溶液 につき, $\mathrm{SnCl}_{6}{ }^{2-}, \mathrm{Sn}(\mathrm{OH}) \mathrm{Cl}_{5}{ }^{2-}$ などのクロロ錯イオ ンの紫外部の吸収を測る $\operatorname{Sn}(N)$ の定量 ${ }^{37)}$, 硫酸による Bi の定量が述べられた ${ }^{38)}$. また, $\mathrm{H}_{2} \mathrm{~S}$ により微量の $\mathrm{Ru}$ をコロイド状の硫化物に変え, $\mathrm{Ru}$ の比色定量 ${ }^{39)}$, 臭化物溶液中の $\mathrm{Sn}(\mathbb{I})$ すなわち $\mathrm{SnBr}_{2}$ により $\mathrm{Pt}$, $\mathrm{Rh}, \mathrm{Pd}, \mathrm{Ir}, \mathrm{Au}$ などはいずれも特有の着色を呈する. そして Au は例外であるがその他は安定で比色に適する と云われている40). 前期に続いてチオシアン塩が比色試 薬として注目され臭化物, ヨウ化物などの新しい比色法 に応用された41) 43). また, フッ化チタン酸-過酸化水素 を用いる $\mathrm{Sn}(\mathrm{N}), \mathrm{Sb}(\mathrm{V})$ の比色定量法が発表され た44)45).

その他 $\operatorname{Sn}(\mathbb{I})$-強リン酸, $\operatorname{Cr}($ V $)$-強リン酸に関する 研究が引き続いておこなわれ Se, ハロゲン化物の定量 が可能とされ4647)，一方強りン酸-ヨウ素酸を分解郕とす る $\mathrm{N}: \mathrm{C}-\mathrm{N}: \mathrm{Ca}$ 中の窒素の定量 ${ }^{48)}$, なおこの方法をさ らに簡便にし一般分析に応用できるように改良し, 不 揮発性有機体窒素化合物の迅速定量などがおこなわれ た ${ }^{48)}$.

分離の方面では, $\mathrm{K}, \mathrm{Rb}, \mathrm{Cs}$ の難溶性塩の溶解度間 の関係が種々検討された結果, $\mathrm{K}-\mathrm{Rb}$ の分離に $\mathrm{Na}_{2} \mathrm{Ag}$. $\mathrm{Bi}\left(\mathrm{NO}_{3}\right)_{6}$ が用いられ， $\mathrm{Rb}-\mathrm{Cs}$ の分離には濃酢酸中で $\mathrm{KBiI}_{4}$ または $\mathrm{NaBiI}_{4}$ 試薬の適用が注目された50つ 52). つついて一たん $\mathrm{Cs}_{3} \mathrm{Bi}_{2} \mathrm{I}_{9}$ の沈殿として微量の $\mathrm{Cs}$ を分 離したのち, Bi を Dithizon 法で比色し間接に Cs の 定量の研究がおこなわれた53). また Hexachlorotellurous acid を沈殿剂とし $\mathrm{Cs}_{2} \mathrm{TeCl}_{6}$ として分離す る放射性 Cs の定量がのべられた ${ }^{54)}$. 一方無機交換体 として Zr-phosphate, Zr-tungstate, Zr-molybdate, ammonium phospho molybdate などをもちい RbCs の分離する方法が検討され，この方法は有機交換樹 脂法よりは有効であるとの報告があった ${ }^{55}$. 沈殿剤とし $\tau$ Hexa-ammino-cobalt chloride $\left[\mathrm{Co}\left(\mathrm{NH}_{3}\right)_{6}\right] \mathrm{Cl}_{3}$ と $\mathrm{NaF}$ とにより $\mathrm{Al}$ または $\mathrm{Ga}$ の定量分析法や, A1 お よび $\mathrm{Ga}$ の放射分析法, $\mathrm{Ga}$, In, T1 の分離定量法の研 究がなされた ${ }^{56) ~ 59) . ヘ ゙ つ に ~}\left[{ }^{60} \mathrm{Co}\left(\mathrm{NH}_{3}\right)_{6}\right] \mathrm{Cl}_{3}$ により $\mathrm{Bi}$ を $\left[\mathrm{BiCl}_{6}\right]\left[{ }^{60} \mathrm{Co}\left(\mathrm{NH}_{3}\right)_{6}\right]$ として分離しその放射能を測 定して Bi が定量され，同様にして Be の定量も試みら れた ${ }^{60}$ ).

(村木, 佐藤)

\section{交 献}

1) H. J. Keily, A. Eldridge, J. O. Hibbits: Anal. Chim. Acta, 21, 6 ('59); 2) C. Duval, C. Wadier: ibid., 20, 20 ('59); 23, 257 ('60); 3) J. L. Hoffman: Anal. Chem., 31, 1934 ('59); 4) N. B. S.: J. Electrochem. Soc., 105, 194C ('58); 5) S. N. Lurée, I. I. Angelov, V. A. 
Rakovskaya: Trudy Vsesoyuz. Nauch. Issledovatel Inst. Khim Reaktivov, 23, 29 ('59); C. A. 55, 2327 ('61); 6) T. Grendon: Anal. Chem., 32, 300 ('60); 7) W. H. Waggoner: Chemist Analyst, 48, $80\left({ }^{\prime} 59\right)$; 8) 重松恒信: 分化, 8, 261 ('59); 9) 浜口博, 池田長生, 川島敏: 分化, 8, 382 ('59); 10) 四方英治, 山口干鶴子: 分化, 8, 753 ('59).

11) I.I. Angelov, G. A, Rertsay, M.M. Shrarts: Trudy Vsesoyuz. Nauch. Issledovatel Inst. Khim. Raektivov, 23, 31 ('59); C. A. 55, 2328('61); 12) I. I. Angelov, G. A. Pertsov, N. I. Sokolov, N. S. Dmitrieva: Trudy Vsesoyuz. Nauch. Issledovatel Inst. Khim. Reaktivov 23, 40, ('59); C. A. 55, 2328 ('61); 13) D. V. Bezuglyi: Zhur. Prik. Khim., 32, 262 ('59); 14) B. D. Konstantinov, V. R. Rylov; ibid., 32, 1368 ('59); 15) 小林光一: 物理学誌, 15, 1982, '60); 16) I. I. Angelov, V.S. Nachava: Trudy Vsesoyuz. Nauch. Issledovatel Inst. Khim. Reaktivov, 23, 14 ('59), C, A, 55, 2327 ('61); 17) I. I. Angelov, S. Khainson: ibid., 23, 19 ('59); C. A. 55, 2326 ('61); 18) I. I. Angelov, N. S. Dmitriva: ibid., 23, 25, ('59); C. A. 55, 1260 ('61); 19) L. E. McCarley, J. W. Roddy: LessCommon Metals, 2, 29 ('60); 20) A. A. Krawetz, T. F. Young: Ind. Eng. Chem., 51, 229 ('59).

21) S.A.Brusilovskie: Zavodskaya Lab., 24,1204 ('58); 22） 椿勇: 分化, 8, 318 ('59); 23) T. Gaspar, Y. Arnal: Chim. Ind. (Paris) 84, 523 ('60); 24) G. Matsuyama: Chemist Analyst, 49, 21, '60); 25) M. M. Caso, M. Cefola: Anal. Chim. Acta, 21, 205 ('59); 26) I. M. Korenman, F. R. Sheyanova, N. A. Efremov: Trudy Khim. i. Khim. Tekhnol. 2, 400 ('58); A. A. 7, 885, '60); 27) G. Tölgyessy: Magyar Kém. Foly, 65, 149 ('59); A. A. 7,9 ('60); 28) L. Erdey, J. Inczédy; Z. anal. Chem., 188, 410 ('59); 29) J. Haviř: Coll. Czech. Chem. Com-

\section{$6 \cdot 2$ 有}

機

6.2.1 概論 有機試薬に関する交献は非常に多く, 筆者のみた範囲内でも 500 編以上にのぼるが，方法的に みるとその大部分は比色法に用いられる試薬で, 重量,

容量分析に用いられる試薬は少なく，乙たがって有機試 薬の特色は比色法において最も発揮されるものと考えら れるので, 本稿では紙数の関係で比色法に用いられる試 薬に限ることとし，あわせて抽出分離に関する文献をつ け加え，概観することとした. 比色試薬の各論では対象 となる元素によって分類した. 全般的にみて新らしいタ イプの試薬はあまり見出されていないが，従来から広く 用いられている試薬の応用範囲の拡大, 分離定量法にお ける改良, 従来の試薬を種々の誘導体にかえて感度の上 昇, 溶解度の変化などをはかるというような傾向の報告 が多いようである. 対象となる元素では $\mathrm{Cu}, \mathrm{Fe}, \mathrm{Ni}$, Co など重要な金属についての報告が多いが, U, V, $\mathrm{Mo}$, 白金族金属, Se, Te などの試薬について 報告が 多いことが注目される. 総説としては, 有機試薬全般に わたるような総説は見当らないが, 特定の試薬について は, その誘導体をも含めて, 試薬としての有用性を広範 囲に総説したものがある. そのようなものとして，オキ mun., 25, 635 ('60), A. A. 7, 4663 ('60)

30）藤田悦男： 日化, 81, $85\left({ }^{\prime} 60\right)$.

31）高橋昭: 分化, 8, 565 ('60); 32) 榎健表, 原田多賀子, 森坂勝昭, 角谷子: 薬学, 79, 679 ('59); 33) K. Burger, E. Schulek: Z. anal. Chem., 172, 98 ('60); 34) 北川豊吉: 日化, 81, 83 ('60); 35) 山本勇萑: 同上, 80, 1428 ('59); 36) 山本勇栕: 同上, 80, 875 ('59); 37) M. Ishibashi, Y. Yamamoto, Y. Inoue: Bull. Inst. Chem. Res. Kyoto Univ., 37, 38 ('59); 38) 山本勇禁: 日化, 80, 1256 ('59);

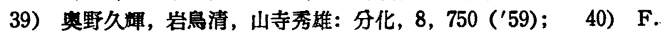
Pantani, G. Piccardi: Anal. Chim. Acta, 22, 231 ('60).

41）岩崎岩次, 森田一郎, 塩田勝, 友成明久, 内海胦: 日化, 80, 744 ('59)； 42）塩田勝, 岩崎岩次, 内海唡; 同上, 80, 753: ('59); 43) 岩崎岩次, 森田一郎, 友成明久, 内海喻: 同上, 80, 749 ('59)； 44）深間队久雄, 榎原竜子, 上原みつ子：分化，8, $\left.315\left({ }^{\prime} 59\right) ; 45\right)$ 深間内久雄, 榎原竜子, 照井聡子, 時本好子, 上原みつ子: 同上, 8, 353 ('59); 46) T. Kiba, I. Akaza, H. Yano: Bull1. Chem. Soc. Japan, 32, 454 ('59)；47) 木羽 微泰, 赤座郁子: 日化, 81，449 ('60); 48) 高木友雄, 柳田勇: 分化, 9, 29 ('60); 49) 瀬戸寿太郎: 同上, 9, 669 ('60); 50) T. Hara: Bull. Inst. Chem. Res. Kyoto. Univ., 37, 112 ('59).

51) T. Hara: ibid., 37, 126 ('59); 52) T. Hara: ibid., 37, 132 ('59); 53) T. Hara: ibid., 37, 139 ('59); 54) H. A. C. Montgomery: Analyst, 85, 687 ('60); 55) C. B. Amphlett, L. A. McDonald: J. Inorg. Nucl. Chem., 10, 69 ('59); 56) 高島良正: 日化, 88, 619 ('59); 57) 高島 良正: 同上, 80, 622 ('59); 58) 高島良正: 同上, 80, 624 ('59); 59) 高島良正: 同上, 80, 626 ('59); 60) I. Demar, I. Gainar, T. Nascutin: Rer. Chim. Bucharest. 11, 291 ('60), A. A. 39 ('61).
シン17) (定性, 容量, 重量, 比色, ケイ光法およびマス キングへの応用), $\beta$-ジケトン類 ${ }^{18)}$ (種々の置換基を有 するものの比較), クロラニル酸19（種々の 金属のほか $\mathrm{SO}_{4}^{-}, \mathrm{Cl}^{-}, \mathrm{F}^{-}, \mathrm{PO}_{4}{ }^{3-}$ などのアニオンへの応用), 七

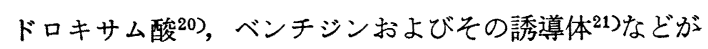
ある.そのほか交献集として Zhur. anal. Khim. 1960 年の報告の紹介 ${ }^{22}$, 比色分析に用いる有機試薬の紹介 ${ }^{23}$, がある。

\section{$6 \cdot 2 \cdot 2$ 各 論}

比色分析用試薬 Al アルザリン系の化合物としては キニザリンスルホン酸1)，そのほかピロカテコールバイ オレット2が報告され，オキシネートとしての Tiより の分離定量法3) の報告がある.

$\mathrm{Au} \mathrm{Sb}$ の試薬であるローダミン B が用いられ， Sb が妨害しない条件が検討された4). また比較的新しい試 薬として 2-ピリジルケトキシムも応用されている5).

B 1,1-ジアンスリミドがBの試薬として盛んに研究 されるようになり67)，またモノメチルチオニン8)も用い られるなど，NがBに配位する形の試薬が広く用いられ るようになった点は興味深い.メチルバイオレット9に 
よる方法も考案された。

Be $\beta$-ジケトン系の試薬の利用が多く10111)，アリザ リン系の 2-フェノキシキニザリン-3,4-ジスルホン酸12), クロモトロプ酸のアゾ誘導体 ${ }^{13)}$ ，アルミノン14)などによ る報告もある。

Ca Ca に対する試薬は従来から数が少なく, あまり よいものが見出されていなかったが，グリオキザール． ビス (2-ハイドロキシアニル) ${ }^{176}$ )が微量定量に秀れてい るとの報告があり，また 2-ハイドロキシ-1-(2-ハイド ロキシ-4-スルホ-1-ナフチルアゾ)-3-ナフトエ酸15)を光 度滴定的に用いると $\mathrm{Mg}$ との分離定量によいとの報告 がある. $\mathrm{Mg}, \mathrm{Fe}$ 共存下に拈けるクロラニル酸による方 法も検討された16).

$\mathrm{Cd}$ ジチン゙ンによる $\mathrm{Al}$ 中微量 $\mathrm{Cd}^{24)}$, グリオキザー ル・ビス（2-ハイドロキシアニル）による方法25) があ る.

$\mathrm{Co}$ ニトロソ $\mathrm{R}$ 塩による $\mathrm{Fe}$ 中の $\mathrm{Co}^{26)}$ のほか, 従 来あまりみうけなかった試薬として，オキザミドキシ ム27), ジアセチルモノオキシム-2,4-ジニトロフェニル ヒドラゾン28), N, N'-エチレンージ (4-メトキシ-1,2-ベ ンゾキノンー1-オキシム-2-イミン ${ }^{29)}$ などがあり，また 指示薬であるエリオクロムブラック T ${ }^{30}$, ナフトール31)も利用される.

Cr EDTA を比色的に用いる方法 32 , 従来よりの試 薬であるジフェニルカルバチド（33)，2-テノイルトリフロ ロアセトンによる抽出 ${ }^{34)}$ と定量の報告もある.

$\mathrm{Cu} \mathrm{Cu}$ の分析法についての全般的な総説35)があり， その中に有機試薬による比色法も多く紹介されている. Cu に関する報告は非常に多数にのぼるが，従来用いら れてきたネオクプロインを用いる高純度金中の定量36)の ほか, 新しい試薬として 2,2'-ビキノリルの種々の新誘 導体の試薬としての比較検討 ${ }^{37}$ ～40)，2-ピリジルケトキ シム41), テトラメチレンジチオカルバミン酸ナトリウ ム42)，8-メルカプトキノリン43)などがあり，またピリシ ルアゾナフトール44)による報告もある. また $\mathrm{Cu}$ と反応 し易いと考えられるアルジン系では 2-アミノベンッ アルデヒドエチレンジイミン57)が $\mathrm{Ni}$ との同時定量に用 いられた。

$\mathrm{Fe}$ フェナンスロリン45)46), その誘導体 $(4,7$-ジフェ ニル体) ${ }^{47)}$ による報告が多く, またクッペロン48)も非鉄 金属中微量 $\mathrm{Fe}$ の抽出, 定量に用いられた. ヒドロキサ ム酸誘導体としては新しくキナルジン酸49), イソニコチ ン酸50)など異項環を含むむのの有用性が検討された. 及-ジケトン系としてはジベンゾイルメタン51), アセチル アセトン52) がある. ジピリジル類似試薬と考えられる
2-ピリジルケトキシム類として，メチルケトキシム41), フェニルケトキシム53)がある. そのほかかわった試薬と して種々のトリアジン誘導体が検討されたが，その中で $2,4,6$-トリピリジル-1,3,5-トリアジン54) が最むよいと いう報告があり，3-ハイドロキシー3-メチル-1-フェニル トリアジン55)も同じトリアジン誘導体として用いられ, また 2-(ハイドロキシ-5-メトキシフェニルアゾ)-4-メ チルチアゾール56)も用いられるなど, 水酸基をもつ種々 の異項環化合物が有用であることは注目される.

Ge Bの試薬である 1,1'-ジアンスリミドの応用58), 種々のフラボノイドなど水酸基とカルボニル基を有する 化合物が検討され ${ }^{599}$, またフェニルフルオロン60)による 報告がある.

$\mathbf{H g}$ 新しい試薬は見当らないが，ジチゾンによる有

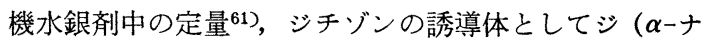
フチル） チオカルバゾン62)がある.

Mg キシリジルブルーによる微量定量 ${ }^{63664)}$ があり, ビスサリチリデンエチレンジイミンを用いるジメチルホ ルムアマイド中での 比色法の報告65) があり, 感度もよ い.

Mo イオウ化合物としてフェニルチオセミカルバチ ド82), 5-フェニル-2-ピラゾリノ-1-ジチオホルメート66), 8-メルカプトキノリン67)があり，ポリハイドロキシ化合 物として 2,3,7-トリハイドロキシ-9-メチル-6-フルオ ロン68), ジハイドロキシケルセチン69なども用いられる など比較的新しい試薬がみられる.

$\mathbf{N i}$ 依然としてジフェニルグリオキシム70), シクロヘ キサン-1, 2-ジオンジオキシム71)のような 1,2-ジオキシ ムが多く用いられ，そのほかメルカプト酢酸71)，2-(ハ イドロキシ-5-メトキシフェニルアゾ)-4-メチルチアゾ ール73)などがある.この試薬では $\mathrm{Co}, \mathrm{Zn}$ も同様に定量 できる74).

Sb 色素類としてクリスタルバイオレット75), メチル バイオレット76)，またトリハイドロキシフルオロン77)の 応用などの報告がある.

Se, Te これらの元素に対する報告数が 相当多いの は，1,1'-ジアンスリミド 78)79)，3,3'-ジアミノベンチ ジン8081)など秀れた試薬の出現によるものであり, 後 者によれば $\mathrm{Te}$ 中の $\mathrm{Se}$ も分離定量できる81) 特徴が ある. またトリハイドロキシフルオロン88)も用いられ る.

Sn よい試薬の出現が望まれているが, ジチオールに よる方法を生体中の微量定量に応用できるよう詳細な検 討がなされ，またフェニルフルオロン ${ }^{87}$ による方法とも 比較されその得失が論じられた。 また, フラボノール類 
も利用できることが見出された ${ }^{88)}$.

Ti 水酸基を有する化合物としてティロン84), 2,3,7トリハイドロキシ-9-メチルフルオロン85) があり, 同じ く水酸基を有する 異項環化合物として 3,7-ジハイド口 キシ-3H-フェノチアジン-3-オン 86) も報告され, $\mathrm{Cr}$ も 同時に定量される.

Th ネオトロン 89), トロン90)などの有機ヒ素化合物 のようによく知られた試薬のほか， 0 -カルボキシフェニ ルアゾクロモトロプ酸11)，2,4-ジクロロフェノキシ酢 酸92)などかわったタイプの試薬が現われた。 またフラボ ノール類としてケルセチンスルホン酸も用いられること が見出された ${ }^{93) . ~}$

$\mathbf{U}$ 新しい試薬や改良法など報告がきわめて多い。主 体は $\beta$-ジケトン類であり, アセチルアセトン94)95), およ びそれを用いる Fe との同時定量 ${ }^{96)}$, ジベンゾイルメタ ン97)，2-テノイルトリフロロアセトン98), のほかに，水 溶性誘導体として $p$-カルボキシジベンゾイルメタン99) などが用いられている. フラボノールについては錯体の 組成，生成定数などが詳細に検討された100) ほか，その 水溶性誘導体としてケルセチンスルホン酸 ${ }^{101) ~ も よ い こ ~}$ とが報告された，そのほかにつぎのような多くの試薬が 報告されている. ビス(2-ハイドロキシフェニルイミノ) グリオキザール102), ピリジルアゾナフトール103), 3-(2アルソノフェニルアゾ)-4,5-ジハイドロキシ-2,7-ナフ タレンジスルホン酸 ${ }^{104)}, 2-(2-$ チアゾリルアゾ)-5-ジメ チルアミノフェノール105), レゾルシノール106), 3-ハイ ドロキシイミノメチルサリチル酸107), ベンツヒドロキサ ム酸108), ニコチナミドキシム109)，またオキシン110)も微 量定量に用いられた。

$\mathbf{V}$ 微量定量法に関する総説111) があり, オキシン, ヒドロキサム酸, ピリジルアゾナフトールなどの錯体に よる方法や, ジェニルアミン類, ヒドラジノフタラジ ンなどの試薬を酸化して呈色せしめ比色する方法など, 多くの有機試薬を用いる方法が記載されている．そのほ かの報告としては，ピリジルアゾナフトール112)113)， NベンゾイルーN-フェニルヒドロキシルアミン114), ベンゾ ヒドロキサム酸177), 6-クロロ-8-メルカプトキノリン115), オキシン116)，ジフェニルアミンスルホン酸117によるも のがある.

Z r Z r の分析化学の総説118) があり，その中に多く の有機試薬が紹介されているが，キシレノールオレン シ 119)120), 2-(p-スルホフェニルアゾ)クロモトロプ酸121), 1,8-ジハイドロキシアゾナフタレン-3,6,4-トリスルホ

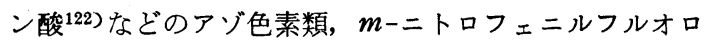
ン128), アリザリンレッド $\mathrm{S}^{124)}$ がある. またケルセチン
スルホン酸125)，モリン126)などのフラボノール類を用い れば Hf との分離定量が行なえるとの報告がある.

Pt 族金属 これらの金属に対する試薬が非常に多く 報告されているのは，これらの金属が安定な錯体を生成 し易いためと考えられる.Pd にはチオサリチル酸127), 1-フェニルチオセミカルバチド128), 2-メルカプトベンツ イミダゾール ${ }^{129), ~ キ ノ キ サ ゙ リ ン-2,3-シ ゙ チ オ ー ル ~}$ メルカプト-4,5-ジメチルチアゾール131)，1-p-クロロフ エニル-3-(4-メチルチアゾリル)-チオ尿素132), ビス(ア リルチオカルバモイルヒドラジン133), N, N'-ビス (3-シ メチルアミノプロピル)-ジチオオキザマイド134)などの ようなイオウ化合物が非常に多いことは興味深い。また オキシム類も多く, 2-チオフェンアルドキシム ${ }^{135)}$, キ， リン-2-アルドキシム ${ }^{136)}$, フェニル-2-ピリジルケトキシ ムのような異項環を含むオキシム類や，4-メチルシクロ ヘキサン-1,2-ジオンジオキシム138) のような 1,2-ジオ キシムがある．またジメチルグリオキシム法を高純度金 中の $\mathrm{Pd}$ の定量用に条件を検討した報告 ${ }^{139)}$ ，ピリジル アゾナフトール140), 2-ニトロソ-1-ナフトール-4-スルホ ン酸141)による報告がある. Os にはアンスラニル酸142)， スルファニル酸143)，1-ナフチルアミン $-4,6,8$-トリスル ホン酸 ${ }^{144)}$ ， Ru には N, N'-ビス (3-ジメチルアミノプ ロピル）ジチオオキザマイド145)， Rh にはメルカプトコ 八ク酸による $\mathrm{Pd}$ との同時定量 ${ }^{146)}$ の報告がある.

そのほかの金属 希土類元素については分析法の 総 説147) がある. ジチゾンによる純金属中の微量 $\mathrm{Pb}^{148)}$, アセトンー水単一相中でのジエチルジチオカルバミン酸 による $\mathrm{Bi}^{149)}$, ネオトロンによる $\operatorname{In}^{159), ~ ト リ フ ェ ニ ル ~}$ テトラゾリウムクロライドによる $\mathrm{Ga}^{151)}$ などの報告が ある・

ケイ光分析用試薬，ケイ光光度計の進歩にともない新 しい研究報告が相当多い. モリンによる In, $\mathrm{Ga}^{152)}$, $\mathrm{Be}^{153)}, \mathrm{Mo}^{156)}$, レザセトフェノンによる $\mathrm{B}^{154)}$, ローダ

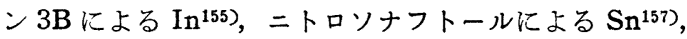
5-メチル-1,10-フェナンスロリンによる $\mathrm{Ru}^{158)}$, ビスサ

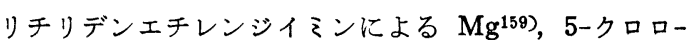
$2,2,4^{\prime}$-トリハイドロキシアゾベンゼン-3-スルホン酸に よる $\mathrm{Ga}^{160)}, 0$-(サリチリデンアミノ)-フェノルによる $\mathrm{Al}^{161)}$, ベンゾインによるホウ酸 ${ }^{162)}$, など興味ある試薬 が多数報告されており, 有機試薬によるケイ光分析は今 後益々発展が予想される.

抽出試薬 比色法に用いる試薬についての報告と重複 するが, 主として抽出, 分離を目的とした研究報告には 次のようなものがある. $\beta$-ジケトン系, オキシン, ジチ ゾンおよびその誘導体による抽出, 分離についての詳細 
な検討, 理論的研究が多いのが目立つ. アセチルアセト ンについては $\mathrm{Fe}$ の抽出 ${ }^{163)}, \mathrm{Be}$ の $\mathrm{Al}$ よりの分離 ${ }^{163)}$, テノイルトリフロロアセトンによる Th の抽出 ${ }^{165)}$. オ キシンでは $\mathrm{Al}$ の抽出168), および, 多数の金属のクロロ ホルム抽出の条件の検討 ${ }^{167)}$ ，また新しい誘導体としてネ オキシン（1-ハイドロキシアクリジン）による $\mathrm{Cu}, \mathrm{Ni}$, Co, Zn の抽出, それらのキレートの安定度の研究 ${ }^{168)}$ があり, ジヂンでは多くの金属の抽出に関する理論的 研究169), $\mathrm{Pb}$ の抽出の検討170)171), 放射性 $\mathrm{Ag}$ を用いる $\mathrm{Ag}$ 抽出の検討172), 誘導体としてジ-1-ナフチルチオカ ルバゾンそのほかの抽出試薬としての検討173) があり,

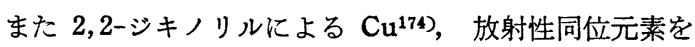
用いるCo のニトロソナフトール抽出の検討175)などの 研究がある.

(田中)

\section{交 献}

1) E. G. Owens, J. H. Yoe: Anal. Chem., 31, 384 ('59); 2) A. Anton: Anal. Chem, 32, $725($ ('60): 3) W. T. Bolleter: Anal. Chem., 31, 201 ('59); 4) H. Onishi: Mikrochim. Acta, 1, 9 ('59); 5) B. Sen: Anal. Chim. Acta, 21, 35 ('59); 6) L. Danielsson: Talanta, 3, 138

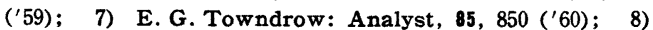
L. C. Paszter, J. D. Bode: Anal. Chem., 32, 1530 ('60); 9）日色和夫, 福田䄧子, 宮出英明: 分化, 9, $71\left({ }^{\prime} 60\right)$; 10) E. S. Przhevalski: Zhur. Anal. Khim., 15, 117 ('60); A. A. 7, $4136\left({ }^{\prime} 60\right)$.

11) J. R. Merrill, M. Honda, J. R. Arnold: Anal. Chem., 32, $1420\left({ }^{\prime} 60\right)$; 12) E. G. Owens, J. H. Yoe: Anal. Chem., 32, 1345 ('60); 13) F. S. Frum, G. I. Silov: Trudy Khim. i Khim. Tekhnol., 1958, 405 A. A. 7, 890 ('60)；14）土屋晹平: 分化，9, 934 ('60)；15）简木 利治, 井本博: 同上, 8, 782 ('59); 16) 久保彰治, 题忠一: 同上, 8, 116 ('59); 17) 本島健次: 同上, 8, 67 ('59); 18) 山根 靖弘: 同上, 8, 264 ('59); 19) 上野景平: 同上, 9, 257 ('60); 20) W. W. Brandt: Record Chem. Progr., 21, 159 ('60) C. A. 54, 24092 (' 60$)$.

21) S. J. Lyle: Talanta, 2, 293 ('59); 22) 藤永太一郎, 山本勇栕: 化学, 18, 375 ('61); 23) 石橋雅義, 松井正和: 同上, 15, 1036 ('60); 24) 橋本鹿雄, 田中礼次: 分化, 8, 564 ('59); 25) 大井信一: 同上, 9, 770 ('60); 26) 若松茂雄: 同上, 8, 830 ('59); 27) G. A. Pearse. Jr., R. T. Pflaum: Anal. Chem., 32, 213 ('60); 28) V. D. Anand, G. S. Deshmukh: Naturwissenschaften, 48, 648 ('60); A. A., 7, 3763 ('60)； 29）真島美智雄: 日化, 80, 1260 ('59); 30) A. A. M. Amin, A. Raheen: Z. anal. Chem., 187, 8 ('59).

3i) G. Goldstein: Anal. Chem., 31, 192 ('59); 32) G. D. Boef, W. J. Jong: Anal. Chim. Acta, 23, 557 ('60) C. A., 55, 3293 ('61); 33) G. Halliwell: Anal. Chem., 32, 1041 ('60); 34) S. K. Majumdar, A. K. De: Anal. Chem., 32, 1337 ('60); 35) 石橋雅義, 森井心し: 化学, 15, 340 ('60); 36) 宮本益雄: 分化, 9, 748 ('60); 37) 中野三郎, 薬莣, 79, 310 ('59); 38) 同上, 79, 314 ('59); 39) 同上, 80, $\left.1510\left({ }^{\prime} 60\right) ; 40\right)$ 同上, 80, $1515\left({ }^{\prime} 60\right)$.

41) D. Banerjea, K. K. Tripathi: Anal. Chem., 32, 1196 ('60); 42) E. Kovacs, H. Guyer: Chimia, 13, 164 ('59) C. A., 53, 21409 ('59); 43) A. F. Ievinsh, E. A. Luksha: Izv. Akad. Nauk. Latv. SSR. 4, 61 ('59); A. A., 7, 3628 ('60); 44) B. F. Pease, M. B. Williams: Anal. Chem., 31, 1044 ('59); 45). 石井大道: 分化, 9, 693 ('60); 46) 同 上, 9, 695 ('60); 47) P. Collins, H. Diehl: Anal. Chem., 31, 1692 ('59); 48) 若松茂雄: 分化, 8, 349 ('59);
49) R. L. Datta: J. Indian Chem. Soc., 36, 339 ('59); 50) R. L. Datta: ibid., 38, 285 ('59).

51）重松恒信，田伏正之: 日化，81，262 ('60); 52) 同上: 分化, 8, 710 ('59); 53) F. Trusell: Anal. Chem., 31, 1998 ('59); 54) H. Diehl, E. B. Buchanan: Anal. Chem., 32, 1117 ('60); 55) H. K. L. Gupta, N. C. Sahani: J. Indian Chem. Soc., 36, 87 ('59); 56) 楖原正, 俣野宜久, 川瀬晃: 分化, 9, 344 ('60); 57) 真島美智雄：同上, 9, 202 ('60); 58) O. B. Skaar, F. J. Langmyhr: Anal. Chim. Acta, 21, 370 ('59); A. A., 7, 2664 ('69); 59) 菅野㔬治: 日化, 80, 757 ('59); 60) 山内文雄, 村田旭: 分化., 2, 959 ('60).

61) 金沢純, 佐藤六郎: 分化, 8, 440 ('59); 62) 武井信典: 同上, 9, 288 ('60); 63) 佐藤清, 高内啓一: 同上, 8, 190 ('59); 64）緒方英世, 広井功: 同上, 8, 21('59); 65) C. E. White, F. Cuttita: Anal. Chem., 31, 2087 ('59); 66) A. I. Busov, V. M.Byrke: Vest. Moskov. Univ. Ser Khim., 2, 76 ('60); A. A. 1, 109 ('60); 67) R. B. Golubtsva: Zhur. Anal. Khim., 14, 493 ('59); A. A., 7, 2198 ('60); 68) A. K. Majumdar, C. P. Savariar: Anal. Chim. Acta, 22, 158 ('60); A. A., 7, 4242 ('60); 69) F. L. Chan, R. W. Moshier: Talanta 3, 272 ('60); A. A., 7, 3760 ('60); 70) Z. Gregorowiez: Acta Chim. Acad. Sci. Hung., 18, 79 ('59); A. A., B, 3530 ('59).

71) D. Monnier, W. Haerdi: Anal. Chim. Acta, 20, 444 ('59); A. A., 7, 546 ('60); 72) P. C. Christopher, H. W. Hamme: Appl. Spectroscopy, 13, 7 ('59); A. A., B, 4787 ('59); 73) 柳原正, 俣野宜久, 川碩晃: 分化., 8, 10 ('59); 74) 同上, 8, 14 ('59); 75) K. Studler, I. Janowsak: Coll. Czech. Chem. Commun., 25, 1965 ('60); A. A., 8, 996('61); 76) L. S. Nadezhina: Ref. Zhur. Khim. Abst., 88, 188, A. A., 7, 4222 ('60); 77) M. I. Lu, T. C. Liu: Acta Chim. Sinica, 25, 353 ('59); A. A., 7, 4221 ('60); 78) O. B. Skaar, F. J. Langmyhr: Anal. Chim. Acta, 23, 175 ('60); A. A., 8, 1009 ('61); 79) F. J. Langmyhr, S. H. Omang: ibid, 23, 565 ('60); C. A., 55, 3298 ('61); 80) 北里資郎, 佐伯勇次: 分化., 8, 422 ('59).

81) C. L. Luke: Anal. Chem., 31, 572 ('59); 82) 小林 寿美雄, 田所敏男: 日化, 80, 47 ('59); 83) G. G. Shitereva: Ukrain. Khim. Zhur., 28, 368 ('60); C. A., 55, 2350 ('61); 84) P. N. R. Nichols: Analyst, 85, 452 ('60); 85) A. K. Majumdar, C. P. Savariar: Anal. Chim. Acta, 21, 584 ('59); A. A., 7, 3694 ('60); 86) E. Ruzicka: Coll. Czech. Chem. Commun., 25, 1691 ('60); A. A., 8, 417 ('61); 87) W. Oelschlaeger; Z. anal. Chem., $174,16\left({ }^{\prime} 60\right)$; 88) 岡 好良, 田中玲子: 日化, 81, 1846 ('60); 89) T. Takahashi, S. Miyake: Talanta, 3, 155 ('59); 90) V. I. Kuznetsov, S. B. Savvin: Radiokhimiya 1, 583 ('59); A. A., 8, 447 ('61).

91) A. K. Majumdar, C. P. Savariar: Z. Anal. Chem., 174, 269 ('60); 92) S. K. Datta: Anal. Chem., 31, 195 ('59); 93) 营野卓治: 分化., 9, 319 ('60); 94) 重松恒信, 田伏正之: 同上, 8，253 ('59); 95) 田伏正之, 京大化研報告, 37, 237 ('59); 96) 石橋雅義, 重松恒信, 田伏正之: 日化, 80, 1018 ('59); 97) P. Blanquet: Chim. Anal., 41, 247 ('59); A. A., 7, $974\left({ }^{\prime} 60\right)$; 98) S. M. Khopkar, A. K. De: Analyst, 85, 376 ('60); 99) 山根靖弘, 吉田智子: 分化, 9, 763 ('60); 100) 管野卓治: 同上, 8, 714 ('59).

101）萛野卓治：分化， 8, 633 ('59); 102) E. Bayer. H. Moellinger: Angew. Chem., 11, 426 ('59); 103) I. H. Spinner, F. C. Miller: Rep. CRDC-837, Atomic Energy of Canada, 1959, 8; C. A., 53, 14836 ('59); 104) H. P. Holcomb, J. H. Yoe: Anal. Chem., 32, 612 ('60); 105) E. Sorensen: Acta Chem. Scand., 14, $965\left({ }^{\prime} 60\right)$; 106) P. C. Jain, G. S. Rao: Anal. Chim. Acta, 20, ('59); A. A., B, 3964 ('59); 107) A. K. Ray, P. Ray: J. Indian Chem. Soc., 37, 141 ('60); A. A., 8, 531 ('61); 108) C. E. Mcloan, P. Holkeboer: Anal. Chem., 32, 791 ('60); 109) 
K. K. Tripathi, D. Banerjea: Z. Anal. Chem., 168, 326 ('59); 110) K. Motojima, H. Yoshida, K. Izawa: Anal. Chem., 32, 1083 ('60).

111）武内次夫, 鈴木正己：分化, 9, 965 ('60); 112) 若松 茂雄: 同上, 9, $284\left({ }^{\prime} 60\right)$; 113) F. W. Staten, F. E. D. Huffman: Anal. Chem., 31, 371 ('60); 114) V. Priyadarshini, S. G. Tandon; Chem. \& Ind., 1960, 931: 115) J. Bankovski: Latvijas PSR Zinatnu Akad. Vestis, 1980, 113; C. A., 54, 24080 ('60); 116) R. J. Nadalin, W. B. Brozda: Anal. Chem., 32, 1141；117）深沢力, 高林良和, 平野四藏：分化, 8, 292 ('59); 118) G. W. C. Milner, J. W. Edwards: Analyst, 85, 86 ('60); 119) L. K. Cheng: Talanta, 3, 81 ('59); A. A., 7, 2677 ('60); 120) L. K. Cheng: ibid., 2, 266 ('59).

121) V. M. Peshkova, N. V. Mel'chakova: Izvest. Vysshikh. Ucheb. Zavedenii. Khim. i Khim. Tekhnol., 3, 72 ('60); C. A., 55, 7165 ('60); 122) S. K. Datta: Z. anorg. Chem., 301, ('59); A. A., 7, 2674 ('60); 123) H. Sano: Bull. Chem. Soc. Japan, 32, 299 ('59); 124) 星野 芳夫: 日化, 80, 738 ('59); 125) 同上, 81, $1273\left({ }^{\prime} 60\right)$ : 126) 同上, 81, $1278\left({ }^{\prime} 60\right)$; 127) I. D ema, V. Voicu: Acad. rep. populare Romine, Studii cercetari Chim., 8, 173 ('60); C. A., 55, 22163 ('60); 128) 小松寿美男，滝和夫: 日化, 80, 397 ('59); 129) A. K. Majumdar, M. M. Chakrabarty; Anal. Chim. Acta, 20, 379 ('59); A. A., 7, 157 ('60); 130) D. A. Skoog: Anal. Chem., 31, 1985 ('59).

131) A. J. Radford: Analyst, 85, 445 ('60); 132) 宇野 豊三, 秋浜澄行: 薬誌, 80, 1015 ('60); 133) N. K. Dutt, K. P. S. Sarma: Anal. Chim. Acta, 23, 531 ('60); C. A., 55, 3297 ('60); 134) W. D. Jacobs: Anal. Chem., 32, 512 ('60); 135) S. G. Tandon, S. C. Bhattacharya: Anal. Chem., 32, 194 ('60); 136) 大井信一: 日化, 80, 1151 ('59); 137) S. Buddhadev: Anal. Chem., 31, 878 ('59); 138) C. V. Banks, R. V. Smith: Anal. Chim. Acta, 21, 308 ('59); A. A., 7, 2742 ('60); 139) 宮本益夫: 分化, 9, 925 ('60); 140) 道野鶴松, 中川元吉, 林誠: 日化, 81, 1703 ('60).

141）小松寿美男, 上山靖二：日化, 81, 1094 ('60); 142) A. K. Majumdar, J. G. S. Gupta: Anal. Chim. Acta, 20, 532 ('59); A. A., 7, 1031 ('60); 143) A. K. Majumdar, J. G. S. Gupta: ibid., 21, 260 ('59); A. A., 7, 2242 ('60); 144) E. L. Steele, J. H. Yoe: ibid., 20, 205 ('59); A. A., 6,

\section{$6 \cdot 3$ 指}

前回の総説の方針に従い，その後に発表された新しい 指示薬に重点をおきつつ紹介する.

\subsection{1 pH 指示薬 $\mathrm{pH}$ 指示薬に関する総説1)のほ} か，数こそ少ないが，毎年いくつかの指示薬が新しく発 表されている.たとえば，スルホン酸型の陽イオン交換 樹脂粒を 0 -エチルフェニル-4-チアゾナフチルアミン塩 酸塩で染めたものは強アルカリやピリジンの中和滴定 に，陰イオン樹脂粒をブロムフェノールブルー，クレゾ ールレッド, ブロムクレゾールレッドで染めたものは強 酸の中和滴定に用いられた2)。 また，ニトロン塩酸塩は $\mathrm{pH}$ 6.6〜8.12 で無色より黄色に変わりクロロホルムに 転溶するので着色試料の中和滴定に抽出指示薬として応 用されたし(3)4), フェノールと無水ピロメリット酸の縮合 によって得られたいくつかの化合物が $\mathrm{pH}$ 指示薬として
4796 ('59); 145) W. D. Jacobs, J. H. Yoe: Talanta, 2, 270 ('59); 146) V. L. Wagner, J. H. Yoe: ibid., 239 ('59); 147) 石橋雅義, 桑本融: 化学, 15, 594 ('60); 148) 楖原正, 俣野宣久, 川瀬晃: 分化, 8, 576 ('59)；149）吉田志: 同上, 9, 759 ('60)；150) 松前鼎一: 同上, 8, 167 ('59).

151) T. Pukas: Chem. Anal., (Warsaw), 5, 513 ('60); C. A., 55, 1287 ('61); 152) A. I. Busev, E. P. Shkrobot: Vestn. Moskow. Univ., 4, 199 ('59); A. A., 7, 4168 ('60); 153) Z. Holzbecher, J. Pokorny: Chem. Listy, 54, 470 ('60); A. A., 8, 460 ('61); 154) R. G. Gopala, T. P. Sastri: Z. anal. Chem., 187, 325 ('59); 155) I. A. Blynum, T. K. Dushina: Zavod. Lab., 137 ('59) A. A., B, 4316 ('59); 156) G. Almassy, M. Vigrari: Acta Chim. Acad. Sci. Hung., 20, 243 ('59); A. A., 7, 1729 ('60); 157) J. R. A. Anderson. A. J. Costouls, J.L. Carnett: Anal. Chim. Acta, 20, 236 ('59); A. A., 6, 4708 ('59): 158) H. Veening, W. W. Brandt: Anal. Chem., 32, 1426 ('60): 159) C. E. White, F. Cuttita: ibid., 31, 364 ('60); 160) A. M. Lakin, E. A. Bozhevi-lnov: Zhur. Anal. Khim., 15, 43 ('60); A. A., 7, 4164 ('60). 161) E. A. Bozhevolnov, V. M. Yanishevskaya: Zhur. Vsesoyuz. Khim. Obshchestva im., D. I. Mendeleeva, 5, 356 ('60); C. A., 54, 19294 ('60); 162) C. A. Parker W. J. Barnes: Analyst, 85, 828 ('60); 163) 田伏正之: 京 大化研報告, 37, 245 ('59); 164）重松愠信, 田伏正之: 日化, 80, 159 ('59); 165) G. Goldstein, O. Menis, D. L. Manning: Anal. Chem., 32, 400 ('60); 166) T. Kambara, H. Hashitani: Anal. Chem., 31, 567 ('59); 167) F. Umlnad, K. U. Meckenstock: Z. anal. Chem., 165, 161 ('59); 168) M. Ishibashi, Y. Yamamoto, T. Yamada: Bull. Chem. Soc. Japan, 32, 1064 ('59); 169) H. Irving, R. S. Ramakrishna: Analyst, 85, 860 ('60); 170) O. A. Weber, V. B. Vouk: ibid., 85, 40 ('60).

171) O. A. Weber, V. B. Vouk: ibid., 85, $46\left({ }^{\prime} 60\right)$; 172) 鈴木信男: 分化, 8, 283 ('59); 173) S. Takei, T. Kato: Technol. Repts. Tohoku Univ., 24, 75 ('59); 174) A. J. Leeb, F. Hecht; Z. anal. Chem., 168, 101 ('59); 175) 鈴木信男, 吉田博之: 日化, 80, 1005('59); 176) J. R. W. Kerr: Analyst, 85, 867 ('60); 177) H. Waledziak, K. Gorczynska: Chem. Anal., (Warsaw), 4, 883 ('59); A. A., 7, 4225 ('60).
示 萫

検討された ${ }^{5}$. また，ジヒドロオキシ酒石酸，焦性粘液 酸，アセトンなどの 2,4-ジニトロフェニルヒドラゾン は強アルカリ性領域の $\mathrm{pH}$ 指示薬として使用できること がわかっだ）（混合指示薬としてはフタロシアニン四ス ルホン酸の $\mathrm{Cu}$ 錯塩とメチルレッドの $(3: 2)$ の混合指 示薬が緑色 $\rightarrow$ 赤色を示し7), 同じく Co 錯塩とメチルオ レンジの混合物 $(1: 1)$ は $\mathrm{pH} 3.3 \sim 3.6$ で鋭敏な変色 を示すことが報告されているす. また $\mathrm{pH}$ 指示薬の吸収 スペクトル的研究がなされアゾ, フタレィン, スルホフ タレインの各色素群を吸収曲線の特性によって区別でき ることが明らかにされた ${ }^{9}$.

$\mathbf{6} \cdot \mathbf{3} \cdot 2$ 非水溶媒指示薬 非水溶媒滴定はますます広 く用いられるようになってきたが，それにともない旧来 の指示薬の新しい用途, あるいは新しい指示薬が報告さ 


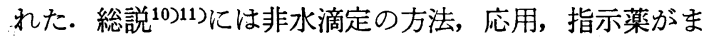
とめられ，また中和滴定指示薬として用いられるクリス タルパイオレットの非水溶媒中での諸性質についてくわ しく研究された ${ }^{12) 13) . ~ ヒ ゙ ク ト リ ア フ ゙ ル ー, フ ゙ リ リ ア ン ト ~}$ グリーン，パラローズアニリンなどが氷酢酸中で14)，ま たベンザンスロンが各種溶媒中で中和滴定指示薬として 用いられた ${ }^{15)}$. さらにチモールブルーはメチルホルムア ミドーメタノール中で 8-ヒドロキシ-5,7-ジョードキノ リンをナトリウムメチラートで滴定する時の指示薬とな り16), ズダン III，ズダン $\mathbb{N}$ ，ナイルブルー A, ニウトラ ルレッド,ブリリアントクレジルブルー, マラカイトグリ ーンなどはベンゼン中でカフェインやテオブロミンを 定量する際に ${ }^{17)}$ ，またメチルバイオレット，ナイルブル 一, サフラニン, ズダン【などは無水プロピオン酸中で ヘナゾン，カフェイン,テオフィリンを滴定する際に ${ }^{18)}$, クリスタルバイオレットはメプロバメートの滴定に ${ }^{19}$ 用 いられた. またクリスタルバイオレットはエフェドリン 塩酸塩の定量にも使用されている20). そのほか $o$-ニト ロアニリンはクロルチアジツトのカ性カリによる非水滴 定指示薬として用いられた21).

6.3.3 酸化還元指示菜 酸化還元滴定法についての 総説 ${ }^{22}$ のほか酸化還元指示薬の一つであるバリアミンブ ルーBについては応用範囲の総説が書かれている23). ま たバリアミンブルーBについてはキノンィミン型への酸 化の過程がポーラログラフ法で研究され24), さらにその 誘導体についても指示薬としての性能が検討された ${ }^{25}$. ベンジジンおよびその誘導体の酸化還元指示薬としての 応用に関しては総説があるほか26), アルコオキシベンシ

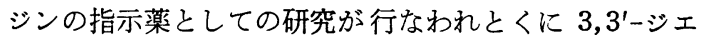
トキシベンジジンはF $\mathrm{Fe}^{2+} に よ る \mathrm{Cr}_{2} \mathrm{O}_{7}{ }^{2-}, \mathrm{Ce}^{4+}$ の滴定の 際に有用であることが報告されている27).そのほか $\mathrm{N}-x$ チルシフェニアルミンー で滴定する時に用いられ28), N-フェニルアントラニール 酸は $\left.\left.\mathrm{Ce}^{4+29) ~ 31)}, \mathrm{VO}_{3}{ }^{-32}, \mathrm{VO}_{4}{ }^{3-} 33\right), \mathrm{Cr}_{2} \mathrm{O}_{7}{ }^{2-34}\right)$ によ る $\mathrm{Fe}, \mathrm{Mo}, \mathrm{U}$ の滴定に用いられた. 変わった指示薬 としてカルシウムシリサイドに塩酸を作用して得られる シロキセンは酸化還元にともない緑赤色のケイ光を可逆 的に発生消失するので, 着色試料の滴定に便利でたとえ ば $\mathrm{MnO}_{4}{ }^{-}, \mathrm{Ce}^{4+}, \mathrm{Cr}_{2} \mathrm{O}_{7}{ }^{2-}$ 滴定に用いられた ${ }^{35) 36}$ )。また ブルシンは $\mathrm{Mo}$, キノールを $\mathrm{Ce}^{4+}$ で37), $\mathrm{Fe}^{2+}, \mathrm{U}^{4+}$, キノールを $\mathrm{Cr}_{2} \mathrm{O}_{7}{ }^{2-}$ で38) 滴定する時の指示薬に用いら れたし，この種の滴定にはエリオグラウシン $\mathrm{A}$ ，エリオ グリーン $\mathrm{B}$ ，キシレンシアノール FF などのトリフェニ ルメタン系色素も指示楽として用いられている39). キシ レノールブルーやメタニールエローは $\mathrm{As}, \mathrm{Sb}$ を $\mathrm{BrO}_{3}-$
で滴定するときの指示薬として用いられ40), サフラニン Tとニウトラルレッドは有機物の還元に用いられた過剩 の $\mathrm{VO}^{2+} \mathrm{Fe}^{2+}$ で逆滴定するときの指示薬として用 いられた ${ }^{41}$. でんぷん指示薬は昔から使用されているが とくにアミローズでんぷんを使用して良い結果が得られ ており ${ }^{42)}$ ，またへナゾンがョードの吸着戍としてでんぷ ん指示薬とともに用いられた ${ }^{43)}$. フタロシアニン四スル ホン酸の $\mathrm{Cu}$ 錯䘏は $\mathrm{Fe}, \mathrm{U}, \mathrm{Mo}$ を $\mathrm{VO}_{4}{ }^{3-}$ で滴定す る時の指示薬に使われ44), またフェロインはシュウ酸を $\mathrm{Ce}^{4+}$ で滴定するときの指示薬に応用された ${ }^{45)}$. そのほ か 0 -ジアニジンは $\mathrm{Bi}$ を氷酢酸中で $\mathrm{Fe}(\mathrm{CN})_{6}{ }^{4-}$ で滴定 する時の指示薬となり46), 3-メチルベンゾチアゾリンー 2-アジノ-5-(5,8-ジヒドロ-8-ヒドロキシキノリン) は $\mathrm{Cu}$ を $\mathrm{Fe}^{2+}$ で滴定する時に選択的な色素としてバリア ミンブルーBとともに用いられた ${ }^{47)}$. またセトグラウシ ンO，アストラブル-G は $\mathrm{Cl}^{-}, \mathrm{F}^{-}$を $\mathrm{Hg}^{2+}$ で滴定す る時に $\mathrm{K}_{4} \mathrm{Fe}(\mathrm{CN})_{6}$ と併用して指示薬として用いられ た48).

$6 \cdot 3 \cdot 4$ 金属指示薬 キレート滴定に用いられるア ゾ, フタレインおよびスルホフタレイン系の金属指示薬 はすでに出つくしたように思われるけれどもいまだ各種 の文献に散見され，またそれ以外のまったく新しい構造 をもった金属指示薬あるいはケイ光金属指示薬が次第に 発展しつつある.

金属指示薬の変色の鋭敏度 ${ }^{49}$ や変色過程 ${ }^{50551) に つ い て ~}$ 理論的な取り扱いが発表されているほか $\mathrm{Ca}, \mathrm{Mg}$ の指 示薬に用いられたアゾ化合物が総説にまとめられ52)，工 リオクロームブラックTの標準品が合成されてそのいろ いろな特性が検討された ${ }^{53}$ ). アゾ化合物に属する新しい 金属指示薬としてはカルマガイド [1-(2-ヒドロキシ-5メチルフェニルアゾ)-2-ナフトール-4-スルホン酸] が 合成されエリオクロームブラック Tと同様に用いられ， しかも安定な点がすぐれているといわれる54)。 マゴン [3-ヒドロキシ-4-o-ヒドロキシフェニルアゾナフト-2', $4^{\prime}$-キシリジド] は pH 10 で 0〜100 $\mu \mathrm{g}$ の Mgのキレー ト滴定に用いられた ${ }^{55)}$. またヒドロン I [1-ヒドロキシー 2-o-ヒドロキシフェニルアゾ-8-アミノナフタリン-3, 6ジスルホン酸] は 100 倍量の $\mathrm{Mg}$ が過剩共存しても $\mathrm{Ca}$ を滴定するのに有効な金属指示薬である56)。 クロモト口 ープ $2 \mathrm{C}$ [o-カルボキシフェニルアゾクロモトロープ酸］ が Th, Zr, Fe の金属指示薬として用いられ ${ }^{5758), ~}$ SNADNS-5 またはー6 [1,8-ジヒドロキシ-2-(5,または 6-スルホナフチルアゾ) ナフタリン-3,6-ジスルホン酸] や CHPADNS [2-(4-カルボキシ-3-ヒドロキシフェニ ルアゾ)-1,8-ジヒドロキシナフタリン-3,6-ジスルホン 
酸]も Th の金属指示薬に用いられた ${ }^{599}$. オキシン誘 導体のアゾ化合物としては SNAZOX [8-ヒドロキシー 7-(4-スルホ-1-ナフチルアゾ) キノリン-5-スルホン酸] が $\mathrm{Bi}, \mathrm{In}, \mathrm{Pb}, \mathrm{Fe}, \mathrm{Cu}, \mathrm{Zn}, \mathrm{Co}, \mathrm{Ni}, \mathrm{Cd}, \mathrm{La}, \mathrm{Hg}$, $\mathrm{Al}, \mathrm{Ga}$ の金属指示薬に $\left.{ }^{60}\right)$, オキシンブルーやピロカテ コールブルーが $\mathrm{Cu}, \mathrm{Zn}, \mathrm{Cd}$ の金属指示薬に使われ61), さらに PAN, PAR に類似のチアゾール誘導体のいく つかが弱酸性で $\mathrm{Cu}, \mathrm{Ni}, \mathrm{Co}, \mathrm{Zn}, \mathrm{Hg}$, In, La など の金属指示薬に用いられた報告がある62) 64). その他の アゾ化合物では Acid Alizarin Black-SN が Ca の65). 66), Elinamina Blue FFL が Th $の^{67)}$, Eriochrome Blue-SE が Ca の ${ }^{68)}$, Metomega Chrome Blue BBL が $\mathrm{Mg}, \mathrm{Ca}, \mathrm{Zn}, \mathrm{Mn}, \mathrm{Ce}$ の $^{69}$, Metomega Chrome Cyanine が $\mathrm{Zn}, \mathrm{Cd}, \mathrm{Mn} の^{70}$ ), Omega Chrome Black $\mathrm{PPV}$ が $\mathrm{Zn}, \mathrm{Cd}, \mathrm{Mn}, \mathrm{Ni}, \mathrm{Pb}, \mathrm{Mg}$ の $^{71}$, Omega Chrome Fast Blue $2 \mathrm{G}$ が $\mathrm{Mg}, \mathrm{Ca}, \mathrm{Mn}, \mathrm{Ni} の^{72}$, Omega Chrome Black Blue G が $\mathrm{Zn}, \mathrm{Cd}, \mathrm{Mn}$, $\mathrm{Pb}$ の $^{73)}$, Omega Chrome Blue Green $か ゙ \mathrm{Ca}, \mathrm{Mg}$ の74), Omega Chrome Green BLL が $\mathrm{Cu}, \mathrm{Pb}, \mathrm{Th}$, A1 の75), Plasmocorinth $\mathrm{B}$ が $\mathrm{Ca}, \mathrm{Mg} の^{76)}$, Solochrome Green V が $\mathrm{Zn}, \mathrm{Mn}$ の $^{77)}$, Solochrome

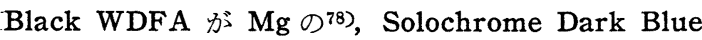
$\mathrm{B}$ が $\mathrm{Ca}$ の $^{78)}, \mathrm{PAR}$ が $\mathrm{Cd}, \mathrm{Hg}, \mathrm{Mn}, \mathrm{Pb} の^{79)}$, ネ オトリンが希土類を La で逆滴定するときの ${ }^{80)}$ ， また Th を直接滴定するときの ${ }^{81)}$ 金属指示薬として用いられ た。

新しい型の金属指示薬としては，H酸の誘導体である カルシクロームがアルカリ性で 20 倍量の Ba の共存下 に Ca を CyDTA で選択的に滴定するときに用いら 㣗82)，また $\mathrm{Ca}$ の選択的な金属指示薬としてグリオキザ ールーbis-(o-ヒドロキシアニル)，が報告された ${ }^{83) ~ 85) . ~}$ さらにインドフェノール類のイミノ三酢酸誘導体のいく つかが合成されとくにインドフェロンが Th, Fe, Bi の 金属指示薬として使われ86)，キニザリン誘導体にも金属 指示薬として有効なものがあり 2-フェノキシキニザリ ン-3,4-ジスルホン酸は Thの指示薬として ${ }^{87)}, 2-\mathrm{N}, \mathrm{N}$ ジ（カルボキシメチル） アミノメチルキニザリンは Ca の金属指示薬として用いられた ${ }^{88)}$.

ケイ光金属指示薬は近年急速に 発展して来た感があ り，そのケイ光発生の機構に関していろいろと意見がか

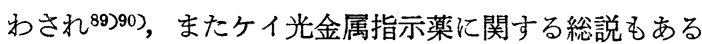
92). カルセインについてその純品が合成されいろいろの 特性が研究されており ${ }^{93)}, \mathrm{Co}, \mathrm{Fe}, \mathrm{Cr}, \mathrm{Cu}$ のケイ光金属指

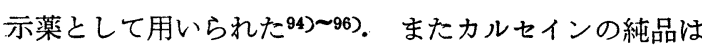
カルセイン W の名前でも呼ばれ $\mathrm{Al}, \mathrm{Ti}, \mathrm{Ni}$ を $\mathrm{Cu}$ で
逆滴定するとき97)，Cu をトリエチレンテトラミンで滴 定するとき98)に使われた. クマリンを母核とするカルセ ン類似体であるカルセインブルーは弱酸性, 中性でCuで 逆滴定するとき, および強アルカリ性で $\mathrm{Ca}, \mathrm{Ba}, \mathrm{Sr}$ 直接滴定するときのケイ光金属指示楽となり ${ }^{999}$, またこ のケイ光金属指示薬はウンベリコンプレクソンの名前で も用いられている100). これに類似の指示薬にはキサン トコンプレクソン100) がありカルセインブルーと同様の 用途が期待されている.

このほか, 類似化合物としてメチルカルセインブルー やメチルカルセインが EDTA-OH をもちいて Cu で $\mathrm{Al}, \mathrm{Ni}$ を逆滴定するときにケイ光金属指示薬として選 択性を発揮することが報告されている101)，またベンジシ ンおよびその誘導体にイミノ三酢酸基を導入したものは ベンシシジコンプレクソンと呼ばれ $\mathrm{Cu}, \mathrm{Ca}$ のケイ光金 属指示薬に用いられている102), ケイ光金属指示薬ではな いがルシゲニンやルミノールが $\mathrm{Cu}, \mathrm{Pb}, \mathrm{Hg}$ をDTA で滴定するときの化学発光金属指示薬として提案されて いる103). その他, キシレノールオレンジの分解生成物は $\mathrm{Cu}$ の金属指示薬として使える事が報告されており ${ }^{104),}$ キシレノールオレンジ-Fe $\mathrm{Fe}^{2+}$ が $\mathrm{Fe}^{3+}$ の105), キシレノー ルオレンジーフェナンスロリンが $\mathrm{Cu}^{2+}$ の $^{106)}$, カルミン 酸が Th, Ce, La の ${ }^{107)}$ 金属指示薬として用いられた.

6.3.5 その他の指示菜金属指示薬を沈殿滴定に応

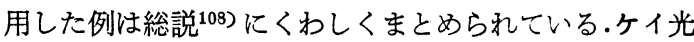
指示薬に属するものとしては八ロゲンイオンや $\mathrm{SCN}^{-}$ を $\mathrm{Ag}^{+}$で滴定する時にマグダラレッド109) やエタクリ ジン乳酸塩, トリパンレッドの酸化物, リボフラビン, オーラジン G,インジゴゾルブルー-IBC などが110)ケイ 光吸着指示薬として用いられ，チオフルオレセインはア ルカリ性で青色のケイ光を発し $\mathrm{Hg}, \mathrm{Ag}, \mathrm{Cu}$ で消失する がチオグリコール酸で復元するのでこれらのイオンの滴

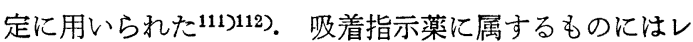
ゾルシンフタレイン, サクシニルフルオレセインなど が吸着指示薬として有効であることが 報告されている (113), O-ジアニシジンが $\mathrm{K}_{4} \mathrm{Fe}(\mathrm{CN})_{6}$ で $\mathrm{Ag}^{+}$を114),

$\mathrm{Zn}$ を(115)滴定するときに吸着指示薬として用いられ，バ リアミンブルーB $\mathrm{B} \mathrm{Hg}^{2}+$ でハロゲンイオンを滴定する 際に吸着指示薬として使われたが116)， $\mathrm{Cl}^{-}$の滴定には 硫酸塩の方が塩酸塩よりも有利である117). また $\mathrm{Cl}^{-}$を $\mathrm{Hg}^{2+}$ で滴定するときジフェニルカルバゾン $-\mathrm{HNO}_{3}$-キ シレンシアソール FF の混合指示薬が用いられ(18), 同 様にジフニルカルバゾン-2-ニトロソナフトールの混 合指示薬も応用されている119). フェノールと無水ピロ メリット酸より合成されたいくつかの化合物も吸着指示 
薬として検討され120)，エリオグリーンＢ む八ロゲンイ オン, $\mathrm{SCN}^{-}$を $\mathrm{Ag}^{+}$で滴定する際に応用され，メチル オレンジとの混合指示薬はさらに明りょうな変色を示 す121). p-ジメチルアミノベンジリデンローダミンや Nメチルアニリノ-5-ローダニルペンタメチンは $\mathrm{CCl}_{4}$ を 抽出溶媒として用いるとき $\mathrm{Ag}$ 滴定の抽出指示薬として 用いられ ${ }^{122)}$ ，また Ba を $\mathrm{SO}_{4}{ }^{2-}$ で滴定する際にロジゾン 酸バリウムがニトロベンゼンーイソアミルアルコール溶 媒系における界面吸着指示薬として用いられることが報 告されている123)。 その他，ジアクリジル誘導体のいく つかが中和滴定のケイ光指示薬として用いられた ${ }^{124)}$. た滴定の指示薬に属さないが $\mathrm{KMnO}_{4}$ と無水 $\mathrm{Mg}\left(\mathrm{ClO}_{4}\right)_{2}$ との混晶は水分を吸収すると淡紫色より暗かっ色に变わ り $\mathrm{Mg}\left(\mathrm{ClO}_{4}\right)_{2}$ の吸湿能力の指示薬となる $\left.{ }^{125}\right)$.

(上野, 斎藤)

\section{文 献}

1) F. Szabadvary: Acta Chim. Acad. Sci. Hung., 20, 253 ('59); A. A., 7, 1646 ('60); 2) L. Legradi: Magyar Kem. Foly., 66, 76 ('60); A. A., 7, 4097 ('60); 3) A.S. Babenko: Zavodskaya Lab., 25, 653 ('59); A. A., 7, 1647 ('60); 4) A.S. Babenko: USSR Patent, No. 117678, 6th. Feb.; A. A., 7, 2046 ('60); 5) J. A. Bishop: Anal. Chim. Acta, 22, 117 ('60); 6) N. V. Chugreeva: Zhur. Anal. Khim., 15, 391 ('60); A. A., 8, 1347 ('61); 7) T. P. Sastri, S. A. Pratt: Z. anal. Chem., 174, 359 ('60); 8) T. P. Sastri, S. A. Pratt: ibid., 175, $182\left({ }^{\prime} 60\right)$; 9) 武者 宗一郎, 杉本健一: 分化, 8, 81 ('59); 10) J. A. Gautier: Bull. Soc. Chim. France, 279 ('59); A. A., 7, 8 ('60).

11) J. Kenttämaa, E. Heinonen: Suomen Kem., 32, 189 ('59), A. A., 7, 2047 ('60); 12) R. C. Paul, J. Singh, S. S.Sandhu: J. Indian Chem. Soc.,, 38305 ('59); A. A., 7, 1247 ('60); 13) R. Reiss: Z. anal. Chem., 167, 16 ('59); 14) O. W. Kolling, M. L. Smith: Anal. Chem., 31, 1876 ('59); 15) R. C. Paul, J. Singh, S. S. Sandhu: ibid., 31, 1495 ('59); 16) H. H. Kavarana: Am. J. Pharm., 131, 184 ('59); A. A., 7, 1552 ('60); 17) M. Rink, R. Lux: Deut. Apoth. -Ztg., 99, 1051 ('59); A. A., 7, 1541 ('60); 18) H. Ellert, T. Jasiński, I. Pawelczak: Acta Polon. Pharm., 16, 235 ('59); A. A., 7, 255 ('60); 19) B. Salvesen, O. Solli: Medd. Norsk. Farm Selsk., 21, 85 ('59); A. A., 7, 1902 ('60); 20) R. P. -Fabini, K. König: Pharm. Zentralh., 98, 176 ('59); A. A., 7, 246 ('60).

21) S. -L. Chang: Acta Pharm. Sinica, 7, 295 ('59); A. A., 7, 1909 ('59); 22) A. M. G. Macdonald: Ind. Chem., 35, 293, 505 ('59); A. A., 7, 1637 ('60); 23) L. Erdey: Chemist Anayst, 48, 106 ('59); 24) E. Banyai, P. Zuman: Collection Czecnoslov. Chem. Commun., 24, 522 ('59); A. A., B, 4251 ('59); 25) L. Erdey, E. Banyai, E. B. -Gere: Talanta, 3, 54 ('59); 26) S. J. Lyle: ibid., 2, 293 ('59); 27) D. I. Rees, W. I. Stephen: ibid., 2, 361 ('59); 28) B. Salovius, V. P. Hirsjärvi, M. Uosukainen: Mikrochim. Acta, 357 ('60); 29) R. Belcher, D. I. Rees, W. I. Stephen: Chem. Anal. (Warsaw), 41, 397 ('59); A. A., 7, 2600 ('60); 30) G. G. Rao, M. Suryanarayana; $Z$. anal. Chem., 180, 177 ('59).

31) J. O. Page, A. B. Gainer: Anal. Chem., 31, 1399 ('59); 32) S. M. Efros, E. S. Boichinova, V. F. Chuprik: Trudȳ Leningr. Tekhnol. Inst. Lensovet., 165 ('58); A. A., 7, 899 ('60); 33) V. M. Evenigorodskaya, M. I. Ryanicheva: Zhur. Anal. Khim., 14, 457 ('59); A. A., 7,
2206 ('60); 34) M. Suryanarayana, G. G. Rao: Z. anal. Chem., 173, 353 ('60); 35) L. Erdey, I. Buzas, L. Polos: ibid., 169, 187 ('59); 36) L. Erdey, I. Buzas, L. Polos: ibid., 169, 263 ('59); 37) T. P. Sastry, G. G. Rao: ibid., 169, 422 ('59); 38) G. G. Rao, T. P. Sastry: ibid., 172, 28 ('60); 39) V. P. Rao, G. G. Rao: ibid., 168, 172 ('59); 40) M. Mitranescu: Acad. rep. populare Romine, Baza cercetari stiint. Timisoara, Studii cercetari stiint. Ser. Stiintechim., 8, 53 ('59); A. A., 55, 1273 ('61).

41) M. Matrka, Z. Sagner: Chem. Průmysl(Prague), 8, 526 ('59); A. A., 7, 2601 ('60); 42) L. Erdey, L. Polos: Period. Polytech., 4, 157 ('60); A. A., 8, 426 ('61); 43) E. Schulek, K. Burger: Pharm. Zentralh., 98, 242 ('59); A. A., 7, $509\left({ }^{\prime} 60\right)$; 44) G. G. Rao, T. P. Sastri: Z. anal. Chem., 187, 1 ('59); 45) V. P. Rao, G. G. Rao: Talanta, 2, 370 ('59); 46) H. Basinska, K. Orylska: Chem. Anal. (Warsaw), 4, 523 ('59); A. A., 7, 2692 ('60); 47) C. Mahr, B. Seeger: Z. anal. Chem., 171, 343 ('54); 48) J. Bognar, L. Nagy: Magyar Kém. Foly., 65, 335 ('59); A. A., 7, 2218 ('60); 49) C. N. Reilley, R. W. Schmid: Anal. Chem., 31, 887 ('59); 50) C. N. Reilley. H.A.Flaschka, S. Laurent,B. Laurent: ibid., 32, 1218('60).

51) C. N. Reilley, E. H. Smith: ibid., 32, 1233 ('60); 52) H. Dieh1, J. Ellingboe: ibid., 32, 1120 ('60); 53) H. Dieh1, F. Lindstrom: ibid., 31, 414('59); 54) F. Lindstrom, H. Diehl: ibid., 32, 1123 ('60); 55) R. H. Maier: Nature, 183, 461 ('59); A. A., 6, 2837 ('59); 56) I. S. Mustafin, E. S. Kruchkova: Zhur. Anal. Khim., 15, 20 ('60); A. A., 7, 4098 ('60); 57) A. K. Majumdar, C. P. Savariar: Z. anal. Chem., 174, 197 ('60); 58) A. K. Majumdar, C. P. Savariar: Naturwissenschaften, 46, 323 ('59); A. A., 7, 340 ('60); 59) S. K. Datta: J. Sci. Ind. Res. India, 19, 168 ('60); A. A., 8, 985 ('61); 60) G. Guerrin, M. V. Sheldon, C. N. Reilley: Chemist Analyst, 49, $36(' 60)$.

61) M. Wronski: Chem. Anal. (Warsaw), 4, 641 ('59); C. A., 54, 9842 ('60); 62) B. S. Jensen: Acta Chem. Scand., 14, 927('60); A. A., 7, $5132\left({ }^{\prime} 60\right)$; 63) U. Svoboda: Talanta， 4, $\left.20\left({ }^{\prime} 60\right) ; 64\right)$ 柳原正，俣野宣久，川㖽晃: 分化, 8, 10, 14 ('59); 65) R. A. Close, T. S. West: Anal. Chim. Acta, 23, 261 ('60): 66) R. A. Close, T. S. West: ibid., 23, 370 ('60); 67) M. R. Zaki, K. Shakir: Z. anal. Chem., 174, $274\left({ }^{\prime} 60\right)$; 68) J. S. Bullock, R. H. Maier: Anal. Chim. Acta, 20, 419, '59); 63) A. A. Abd El Raheem, M. M. Dokhana: Z. anal. Chem., 168, 165 ('59); 70) A. A. Abd El Raheem, M. M. Dokhana: Anal. Chim. Acta, 20, 133 ('59).

71) A. A. Abd El Raheem, A. A. Amin: Z. anal. Chem., 165, 416 ('59); 72) A. A. Abd El Raheem: ibid., 167, 98 ('59); 73) A. A. Abd El Raheem, F. A. Osman: ibid., 169, 328 ('59); 74) A. A. Abd E1 Raheem, A.S. Moustafa: Anal. Chim. Acta, 21, 379 ('59); 75) A. A. Abd El Raheem, A.S. Moustafa, A. A. Amin: Z. anal. Chem., 175, 19 ('60); 76) G. S. Kovacs, K. E. Tarnoky: Anal. Chim. Acta, 21, 297 ('59); 77) A. A. Amin, H. Khalifa, A.S. Moustafa: Z. anal. Chem., 173, 138 ('60); 78) F. Hobson, W. H. Stephenson: Analyst, 84. 520('59); 79) P. Wehber: Z. anal. Chem., 188, 186 ('59); 80) R. S. Lauér, N. S. Poluéktov: Zavodskaya Lab., 25, 391 ('59); A. A., 7, 59 ('60).

81) Y. A. Chernikhov, V. F. Lukyanov, A. B. Kozlova: Zhur. Anal. Khim., 14, 567 ('59); A. A., 7, 2680 ('60); 82) R. A. Close, T. S. West: Talanta, 5, 221 ('60); 83) D. Goldstein: Anal. Chim. Acta, 21, 339 ('59); 84) F. L. Hahn: Z. anal. Chem., 174, 121 ('60); 85) I. Murase: Bull. Chem. Soc. Japan, 33, 607 ('60); 86) V. Svoboda, L. Dorazil, J. Körbl: Collection Czechoslov. Chem. Commun., 25, 1037 ('60); A. A., 8, 10 ('61); 87) E. G. 
Owens, J. H. Yoe: Anal. Chim. Acta, 23, 321 ('60); 88) S. Staukoviansky, V. Podany, F. Jassinger, P. Majer: Chem. Zvesti, 14, 265 ('60); A. A., 7, 4675 ('60); 89) D. H. Wilkins: Talanta, 2, 277 ('59); 90) J. Körbl, V. Svoboda: ibid., 3, 370 ('59).

91) D. H. Wilkins: ibid., 4, 80 ('60); 92) F. Bermejo, A. Badrians, A. Prieto: Inform. de Quim. Anal. (Madrid), 14, 151 ('60); 93) D. F. H. Wallach, D. M. Surgenor, J. Soderberg, E. Delano : Anal. Chem., 31, 456 ('59); 94) D. H. Wilkins: Talanta, 2, 12 ('59); 95) D. H. Wilkins: Anal. Chim. Acta, 20, 324 ('59); 96) D. H. Wilkins, L. E. Hibbs: ibid., 20, 427 ('59); 97) I. E. Hibbs, D. H. Wilkins: Talanta, 2, 16 ('59); 98) D. H. Wilkins, L. E. Hibbs: ibid., 2, 201 ('59); 99) D. H. Wilkins: ibid., 4, 182 ('60); 100) J. H. Eggers: ibid., 4, $38\left({ }^{\prime} 60\right)$.

101) D. H. Wilkins: Anal. Chim. Acta, 23, 309 ('60); 102) R. Belcher, D. I. Rees, W. I. Stephen: Talanta, 4, 78 ('60); 103) L. Erdey, I. Buzas: Anal. Chim. Acta, 22, 524 ('60); 104) R. Pribil: Talanta, 3, 200 ('59); 105) F. Vydra, R. Pribil, J. Körbl: ibid., 2, 311 (59); 106) R. Pribil: ibid., 3, 91 ('59); 107) J. Dobrowolski: Chem. Anal. (Warsaw), 3, 609 ('58); A. A., 7, 57 ('60): 108)
R. Püschel, E. Lassner: Chemist Analyst, , 58, 90, 120 ('60); 109) J. Bognár: Acta Chim. Acad. Sci. Hung., 19, 433 ('59); A. A., B, 4249 ('59); 110) J. Bognár: ibid., 20, 103 ('59); A. A., 7, 6('60).

111) M. Wronski: $Z$. anal. Chem., 175, 432 ('60); 112) M. Wronski: ibid., 169, 351 ('59); 113) U. Kapoor, H. L. Nigam: ibid., 174,179 ('60); 114) H. Basinska, K.Przybyszewska: Chem. Anal. (Warsaw),4,783 ('59);115) 那須高 之助, 熊谷玲子: 分化, 8,306 ('59); 116) Z. Gregorowicz, J. Stoch: Z.anal.Chem., 173,383('60);117) L.Erdey,E. B. -Gere, E. Banyai: Talanta, 3, 209 ('59); 118) E. Goldman: Anal. Chem., 31, 1127 ('59); 119) R. D. Glukhovskaya, N. A. Ugolnikov: Izvest. Vyssh. Ucheb. Zavedenii, Khim. i Khim. Tekhnol., 3, 49 ('60); A. A., 8, 1346 ('61); 120) J. A. Bishop: Anal. Chim. Acta, 22, 221 ('60).

121) F. Icha, M. Valenta: Colletion Czechoslov. Chem. Commun., 24, 2424 ('59); A. A., 7, 1648 ('60); 122) H. Lux, T. Niedermaier, K. Petz: Z. anal. Chem., 171, 173 ('59); 123) 南英一, 螕拔邦彦: 分化, 8, 175 ('59); 124) E. Michalski, M. Turowska: Chem. Anal. (Warsaw), 3, 599 ('58); A. A., 7, 5 ('60); 125) G. F. Smith, H. Dieh1: Talanta, 3, 107 ('59).

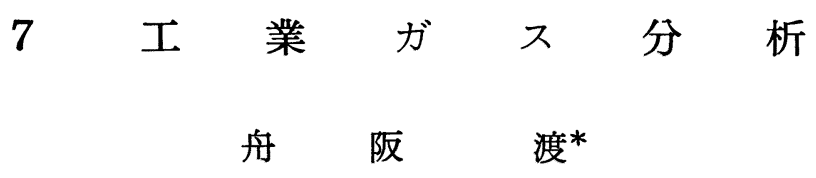

\section{$7 \cdot 1$ ま え がき}

ここでいう工業ガス分析は，以前はガス分析と呼ばれ ていたものである. 最近, 分析化学界でガス分析という と，金属のガス分析を意味するようになっているので， このような題目にした次第である. 一方，この進歩総説 では，これまでに燃料ガス (57 年版, 59 年版); ガスク ロマトグラフィー，質量分析，赤外吸収（ただしいずれ も機器ガス分析の立場である. 58 年版, 60 年版); 水, その他液体に溶けているガスの分析 (58年版, 60年版); 金属のガス分析 (鉄鋼, 非鉄, 57 年版, 58 年版, 59 年 版, 60 年版); 空気污染の立場 (57 年版, 59 年版) な どについて紹介されている. ここでは 1955〜1959 年の 文献を主とし（特殊なものは 1960 年のも入れた)(主と して Analytical Abstractによった), これまでのも のとあまり重複しないように，かつガスの成分をおもな 対象として総説する. 工業ガス分析に関する書物は，だ いたい同年代では若干あるに過ぎない1) 4). また文献紹 介としては Anal. Chem. におけるもの5), その他が少 乙ある67)に過ぎない。

\footnotetext{
* 京都大学工学部工業化学教室 (京都市左京区吉田本町)
}

\section{$7 \cdot 2$ 一般的なもの}

$0.1 \sim 0.001 \mathrm{ml}$ のように非常に微量なガスの分析 ${ }^{8}$ (気 泡の形による), $10^{-2} \mathrm{mmHg}$ のよう低圧における 5〜 $100 \mu l$ のガスの分析9などは興味のあるものであり, 一 方, diffusion による方法; ガスによる滴定; ガス成分 の吸収の前後におけるガス圧の变化による, 音波による, あるいは電気化学的ないし光学的方法による連続自動定 量が多くみられるのは新しい傾向である.なお紙数の都 合があるので，一般的なガス分析の装置に関するもの， ガスの試料採取に関するもの，一般的な燃料ガス分析， 機器ガス分析そのもの（ガスクロマトグラフィー, 質量 分析，赤外吸収など), 金属のガス分析, 水その他液体に 溶けているガスの分析, 空気污染分析そのものなどは, すべて割愛した.

\section{$7 \cdot 3$ 水}

分

水分定量に 関する 検知管による 種々の方法が比較さ れている(10). 一般的には赤外吸収によるものが多くあ る11) 13)ほか, 紫外部吸収 (vacuum u. v. technique) によるもの14)がある. 電気的方法としては吸湿性膜（リ 